Check for updates

Cite this: RSC Adv., 2018, 8, 21679

\title{
Antibody-pHPMA functionalised fluorescent silica nanoparticles for colorectal carcinoma targeting $\dagger$
}

\author{
Denisa Lizoňová, ${ }^{a}$ Monika Majerská, ${ }^{a}$ Vlastimil Král, ${ }^{a b}$ Michal Pechar, ${ }^{c}$ Robert Pola, ${ }^{c}$ \\ Marek Kovár ${ }^{d}$ and František Štěpánek (iD) *a
}

The systemic application of highly potent drugs such as cytostatics poses the risks of side effects, which could be reduced by using a carrier system able to specifically deliver the encapsulated drug to the target tissue. Essential components of a nanoparticle-based drug delivery system include the drug carrier itself, a targeting moiety, and a surface coating that minimizes recognition by the immune system. The present work reports on the preparation, in vitro characterization and in vivo testing of a new delivery system consisting of fluorescent silica nanoparticles functionalised with a non-immunogenic stealth polymer poly( $N$-(2-hydroxypropyl)methacrylamide) (pHPMA) and a monoclonal antibody IgG M75 that specifically binds to Carbonic Anhydrase IX (CA IX). CA IX is a promising therapeutic target, as it is a hallmark of several hypoxic tumours including colorectal carcinoma. Uniquely in this work, the monoclonal antibody was covalently coupled to the surface of fluorescently labelled silica nanoparticles via a multivalent amino-reactive co-polymer rather than a traditional bivalent linker. The pHPMA-M75 functionalised $\mathrm{SiO}_{2}$ nanoparticles exhibited excellent colloidal stability in physiological media. Their in vitro characterisation by flow cytometry proved a highly specific interaction with colorectal carcinoma cells HT-29. In vivo study on athymic NU/NU nude mice revealed that the $\mathrm{SiO}_{2}-\mathrm{pHPMA}-\mathrm{M} 75$ nanoparticles are capable of circulating in the blood after intravenous administration and accumulate in the tumour at tenfold higher concentration than nanoparticles without specific targeting, with a considerably longer retention time. Additionally, it was found that by reducing the dose administered in vivo, the selectivity of the nanoparticle biodistribution could be further enhanced in favour of the tumour.

\author{
Received 23rd April 2018 \\ Accepted 4th June 2018 \\ DOI: $10.1039 / \mathrm{c} 8 \mathrm{ra0} 3487 \mathrm{~g}$ \\ rsc.li/rsc-advances
}

\section{Introduction}

It is known that intravenously (i.v.) administered nanoparticles without specific surface coating are quickly removed from the bloodstream because they are recognized by the immune system..$^{1-3}$ Nanoparticle administration into the bloodstream is usually followed by the adsorption of plasma proteins to the nanoparticle surface (opsonization), ${ }^{\mathbf{1 , 4 5}}$ which induces macrophage phagocytosis. ${ }^{6,7}$ The phagocytosed nanoparticles are then decomposed or stored in the liver, spleen or other organs of the Reticulo-Endothelial System (RES). ${ }^{8}$ Therefore, it is necessary to

${ }^{a}$ Laboratory of Chemical Robotics, Department of Chemical Engineering, University of Chemistry and Technology Prague, Czech Republic.E-mail: Frantisek.Stepanek@vscht. cz; Tel: +420220443236

${ }^{b}$ Laboratory of Structural Biology, Institute of Molecular Genetics of the Czech Academy of Sciences, 14220 Prague 4, Czech Republic

${ }^{c}$ Laboratory of Biomedical Polymers, Institute of Macromolecular Chemistry, Czech Academy of Sciences, Heyrovského Nám. 2, 16206 Prague 6, Czech Republic

${ }^{d}$ Laboratory of Tumour Immunology, Institute of Microbiology of the CAS, v.v.i., Prague, Czech Republic

$\dagger$ Electronic supplementary information (ESI) available: pHPMA synthesis and analysis, additional fluorescent microscopy images, amino acid analysis. See DOI: $10.1039 / \mathrm{c} 8 \mathrm{ra} 03487 \mathrm{~g}$ minimize the protein adsorption if a prolonged nanoparticle circulation is required (e.g. vascular drug delivery, site-specific targeting). ${ }^{9}$ Several materials have been explored in order to prevent protein adsorption and prepare so called "stealth nanoparticles".

Coating by hydrophilic polymers that act as a steric barrier appears to be the most efficient approach (e.g. polyethylene glycol, polyvinyl pyrrolidone, polyvinyl alcohol etc.). ${ }^{5,10,11}$ The most commonly used polymer from this group is polyethylene glycol (PEG), which is considered as a "gold standard" for stealth polymers. However, it offers not only advantages but also certain risks (hypersensitivity reactions, anaphylaxis). ${ }^{\mathbf{1 2 - 1 6}}$ Therefore, alternatives to PEG have been intensively explored recently. Co-polymers based on poly( $N$-(2-hydroxypropyl)methacrylamide) (pHPMA) seem very promising in the field of drugpolymer conjugate delivery and a few candidates have already been tested in clinical trials. ${ }^{12,17}$ pHPMA sufficiently prolongs the blood circulation of such conjugates and thus enables passive tumour accumulation. ${ }^{\mathbf{1 8 - 2 0}}$ Other studies confirmed that pHPMA can create a stealth hydrophilic layer or even enhance the blood circulation in the case of DNA complexes, ${ }^{21}$ selfassembled vesicles, ${ }^{22}$ polymeric particles $^{23}$ or viral vectors. ${ }^{24}$ 
However, pHPMA has not been previously combined with silica based drug carriers.

Apart from prolonging blood circulation, accumulation in the tumour can be further enhanced by active targeting to tumour-specific molecules. One such molecule is Carbonic Anhydrase IX (CA IX), a transmembrane protein overexpressed in several commonly occurring carcinomas. ${ }^{25}$ Thanks to its low expression in the normal tissue ${ }^{\mathbf{2 6}}$ it is a promising target for the delivery of anticancer drugs. ${ }^{27}$ CA IX can be targeted by various moieties such as enzyme inhibitors, ${ }^{47}$ but in order to achieve a truly specific binding, it has been shown that the monoclonal antibody IgG M75 binds CA IX ${ }^{28}$ and specifically accumulates in HT-29 human colorectal carcinoma xenografts in vivo (HT-29 cell line expressing CA IX). ${ }^{29}$ In our previous work it was confirmed that silica nanoparticles bearing IgG M75 antibody can specifically adhere to CA IX antigen under in vitro conditions. ${ }^{30}$ Therefore, the objective of the present was to prepare silica nanoparticles suitable for in vivo experiments by the covalent coupling of IgG M75 in combination with a stealth polymer pHPMA to the nanoparticle surface, and to prove that such nanoparticles are capable of specific accumulation in tumours expressing CA IX.

Beyond the factors mentioned above, particle size is another important parameter that significantly affects the biodistribution, protein adsorption and pharmacokinetics of i.v. administered nanoparticles. Even though smaller particles generally tend to circulate longer, ${ }^{\mathbf{1}, 7}$ the design of multi-compartmental drug delivery devices (e.g. liposome aggregates ${ }^{31}$ ) brings certain

Table 1 Characteristics of silica nanoparticles in demineralized water at different stages of the surface modification

\begin{tabular}{llll}
\hline Nanoparticle type & $\begin{array}{l}\text { Mean diameter } \\
{[\mathrm{nm}]}\end{array}$ & $\begin{array}{l}\text { Polydispersity } \\
\text { index (PDI) }[-]\end{array}$ & $\begin{array}{l}\text { Zeta potential } \\
{[\mathrm{mV}]}\end{array}$ \\
\hline $\mathrm{SiO}_{2}-\mathrm{NH}_{2}$ & $168 \pm 18$ & 0.011 & $+27 \pm 4$ \\
$\mathrm{SiO}_{2}$-pHPMA & $169 \pm 41$ & 0.058 & $-20 \pm 7$ \\
$\mathrm{SiO}_{2}$-pHPMA-M75 & $180 \pm 35$ & 0.038 & $-15 \pm 8$ \\
$\mathrm{SiO}_{2}$-pHPMA-ISO & $165 \pm 36$ & 0.004 & $-13 \pm 7$
\end{tabular}

limitations into the applicable range of particle diameters, especially from below. Silica nanoparticles possess an advantage of tunable size and porosity and thus are intensively studied as carriers for drug delivery. ${ }^{32}$ Such nanoparticles can be functionalized with targeting moieties and transported to the area of interest. ${ }^{33,34}$ When modified with an antibody fragment or a whole antibody, silica nanoparticles can accumulate in the tumour tissue, which can be used not only for treatment, but also for diagnostic purposes. ${ }^{35-37}$ The transported drug or diagnostic probe can be adsorbed to the particle surface or encapsulated in the pores sealed by a gatekeeper system. Moreover, silica is classified as "Generally Recognized as Safe" (GRAS) by the FDA and is used in cosmetics and as a food-additive. ${ }^{32}$ At present, a phase 2 study is conducted with targeted mesoporous silica nanoparticles for image-guided operative sentinel lymph node mapping. ${ }^{38}$

Hence, the present work focuses on the preparation, in vitro characterization, in vivo biodistribution and tumour targeting of $170 \mathrm{~nm}$ fluorescent silica nanoparticles coated by pHPMA with a covalently attached monoclonal antibody IgG M75 as a new, actively targeted drug delivery system.

\section{Results and discussion}

\section{Physico-chemical properties}

Fluorescent silica nanoparticles with covalently bound pHPMA ( $\mathrm{SiO}_{2}$-pHPMA), pHPMA with antibody IgG M75 ( $\mathrm{SiO}_{2}-\mathrm{pHPMA}-$ M75) or irrelevant isotypic antibody ( $\left.\mathrm{SiO}_{2}-\mathrm{pHPMA}-\mathrm{ISO}\right)$ were prepared and characterized. The nanoparticles exhibited mean diameters ranging from 160 to $180 \mathrm{~nm}$ with a polydispersity index under 0.1 (Table 1 ). The zeta potential of uncoated aminosilica nanoparticles was positive $(+27 \mathrm{mV})$ due to the presence of amino-groups on the nanoparticle surface. Polymers based on pHPMA are generally considered of having zeta potential values close to zero. The covalent coupling of pHPMA chains to the nanoparticle surface is done via the aminolysis of aminoreactive thiazolidine-2-thione (TT) groups. These TT groups might be also hydrolyzed, as a side reaction, with the resulting carboxylic groups in the polymeric side-chain introducing a negative charge to the nanoparticle surface (Table 1).
A

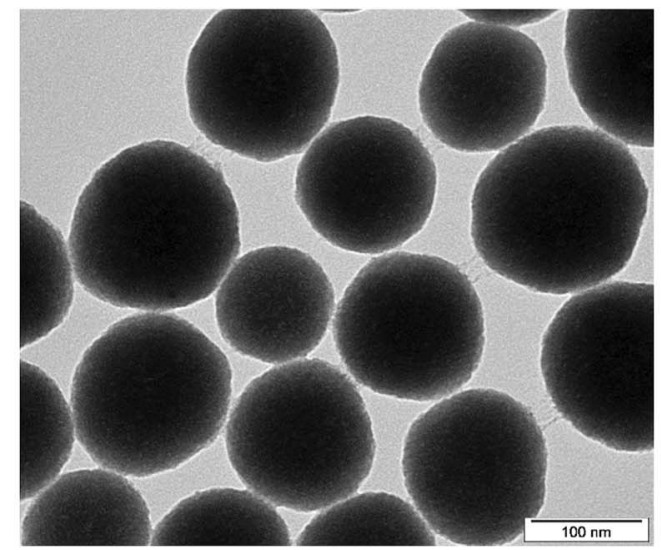

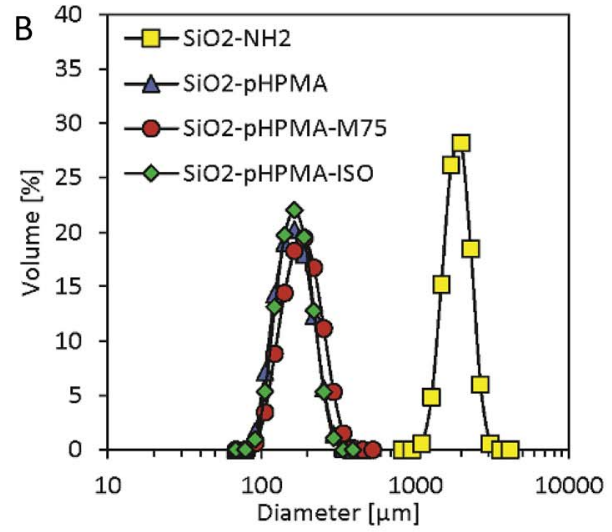

Fig. 1 (A) TEM micrograph of $\mathrm{SiO}_{2}$-pHPMA-M75 nanoparticles; (B) DLS measurements in PBS show colloidal stability when pHPMA is present on the nanoparticle surface. 

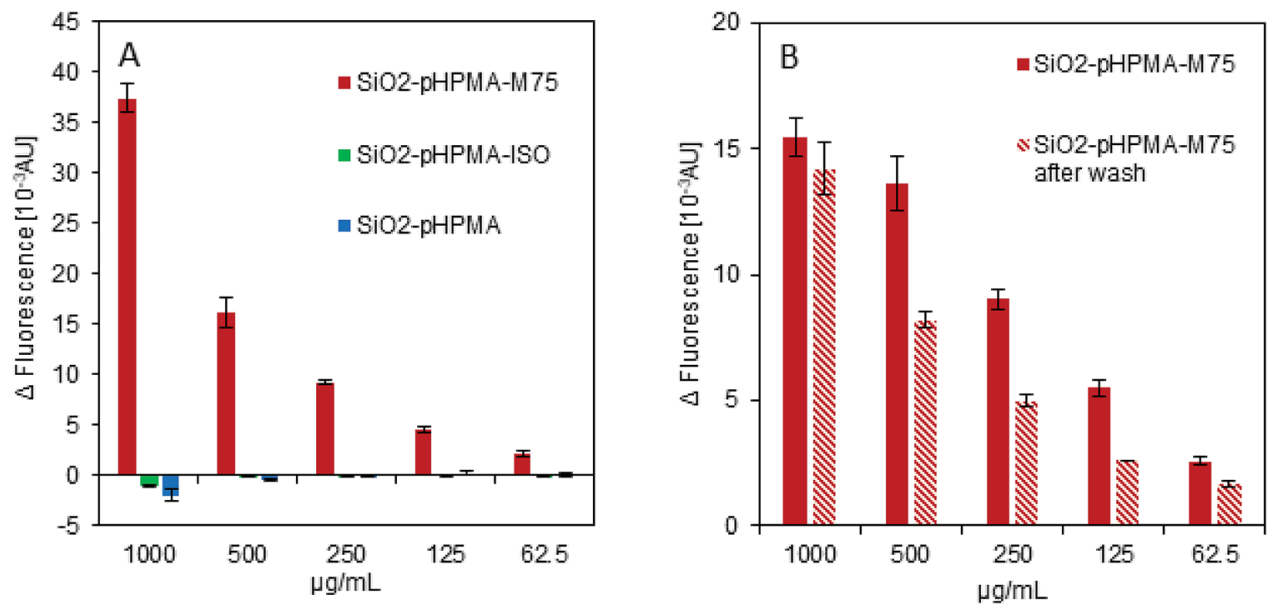

Fig. 2 In vitro characterisation of nanoparticle surface functionalisation. (A) ELISA-like test confirms the presence of the active antibody IgG M75 $\left(\mathrm{SiO}_{2}-\right.$ pHPMA-M75). Nanoparticles without the specific antibody $\left(\mathrm{SiO}_{2}-\mathrm{pHPMA}, \mathrm{SiO}_{2}-\mathrm{pHPMA}\right.$ ISO) do not adhere to the antigen-modified surface. (B) ELISA-like test. Filled columns $-\mathrm{SiO}_{2}-$ pHPMA-M75 nanoparticles after the synthesis, stripped columns - the same batch of the nanoparticles after their repeated wash with PBS $(3 \times)$.

However, when the antibody is attached to the polymermodified nanoparticles via the TT-groups that were not consumed by the reaction with the nanoparticle surface, the measured zeta potential (Table 1) of the final antibodyfunctionalised nanoparticles is less negative than in the absence of the antibody (which is also slightly positively charged).

The final amount of polymer and antibody was measured via amino acid analysis and found to be $36.1 \mu \mathrm{g}$ of pHPMA and $9.5 \mu \mathrm{g}$ of antibody per $1 \mathrm{mg}$ of nanoparticles (3.6 wt\% and $1.0 \mathrm{wt} \%$, respectively), which represents approximately 195 antibody molecules and 2460 pHPMA polymer chains per one nanoparticle, on average. The details of the amino acid analysis and the antibody and polymer quantification are available in ESI 3.†
The results of the morphology and size distribution measurement by Transmission Electron Microscopy (TEM) were in accordance with the data obtained by Dynamic Light Scattering (DLS). The TEM size measurement provided the average nanoparticle diameter of $140 \pm 18 \mathrm{~nm}$. Based on the TEM analysis, it can be concluded that nanoparticles were spherical and possessed a narrow size distribution (Fig. 1).

Nanoparticle colloidal stability in the presence of salts was also of interest due to their intended physiological application and was examined by particle size distribution measurements employing DLS (Fig. 1). While uncoated amino-silica nanoparticles aggregated in phosphate buffer saline (PBS, $10 \mathrm{mM}$; $\mathrm{pH}$ 7.4), all three types of pHPMA-modified nanoparticles formed stable colloidal dispersions due to the steric stabilization caused by the hydrophilic PHPMA polymer chains attached to the nanoparticle surface. Even though these particles
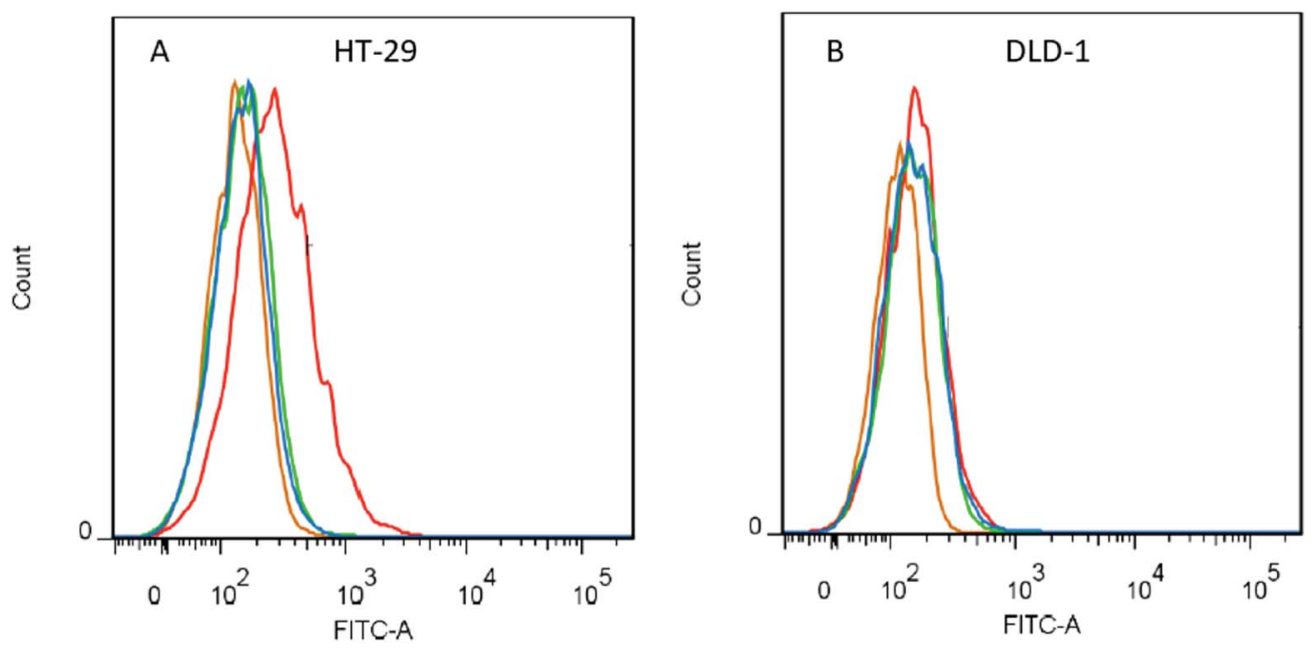

Fig. 3 In vitro characterisation of nanoparticle interaction with cells. Flow cytometry experiment with (A) HT-29 cells expressing CA IX, and (B) DLD-1 cells not expressing CA IX. Red - $\mathrm{SiO}_{2}-$ pHPMA-M75 nanoparticles; green - $\mathrm{SiO}_{2}-\mathrm{pHPMA}-\mathrm{ISO}$ nanoparticles; blue - SiO $2-$ pHPMA nanoparticles; orange - HT-29(A) or DLD-1(B). 
sediment after two weeks of storage at $4{ }^{\circ} \mathrm{C}$ due to their density, they can be quantitatively re-suspended with no change in the particle size distribution.

\section{In vitro behaviour}

The ELISA-like test was used to examine the specific interaction of the antibody IgG M75 with the proteoglycan domain of CA IX in fusion with the Maltose Binding Protein (PG-MBP). Fig. 2A shows the data obtained from fluorescence intensity measurement confirming the functionality of the antibody IgG M75 on the $\mathrm{SiO}_{2}$-pHPMA-M75 nanoparticles. At the same time, nanoparticles without the specific antibody $\left(\mathrm{SiO}_{2}-\right.$ pHPMA and $\mathrm{SiO}_{2}-$ pHPMA-ISO) did not bind to the PG domain of CA IX. No nonspecific interactions of either particle type were observed.

Fig. 2B demonstrates the covalent attachment of the antibody to the nanoparticles examined by repeated washing with a buffer ( 3 times in $1 \mathrm{~mL}$ of PBS). The active antibody is present after the washing and therefore it might be concluded that the antibody is covalently attached to the nanoparticle surface rather than simply adsorbed. The fluorescence intensity decrease at some dilutions might be due to the partial nanoparticle loss during the washing steps caused by the fact that pHPMA coating increases the dispersion stability and thus complicates the nanoparticle centrifugation.
The flow cytometry experiments (summarized in Fig. 3) were carried out to prove that only the specific antibody-antigen interactions are responsible for binding of the $\mathrm{SiO}_{2}-$ pHPMAM75 nanoparticles to the target HT-29 cells. In the case of fluorescent nanoparticles adhered to the cell surface, the measured fluorescence signal of the cell is increased. Positive control experiments (free IgG M75 and a secondary antibody GAM-FITC) confirmed the presence of CA IX antigen on the HT29 cells. At the same time, there were no interactions between the control antibodies and a DLD-1 cell line (which does not express CA IX).

Fig. 3A shows the results of testing with the HT-29 cell line. Since the $\mathrm{SiO}_{2}-$ pHPMA-M75 nanoparticles specifically adhere to the cell surface, an increase of fluorescence intensity was detected. There was no signal shift observed in the case of either $\mathrm{SiO}_{2}$-pHPMA or $\mathrm{SiO}_{2}$-pHPMA-ISO nanoparticles. In the case of DLD-1 cells (Fig. 3B), which do not express CA IX, no significant difference in the fluorescence intensity among the tested nanoparticles was observed. The obtained data indicate that the tested nanoparticles do not interact with the cells nonspecifically.

The fluorescence microscopy experiments (Fig. 4) showed results consistent with the flow cytometry experiments. Nanoparticles bearing the specific antibody IgG M75 $\left(\mathrm{SiO}_{2}-\mathrm{pHPMA}-\right.$
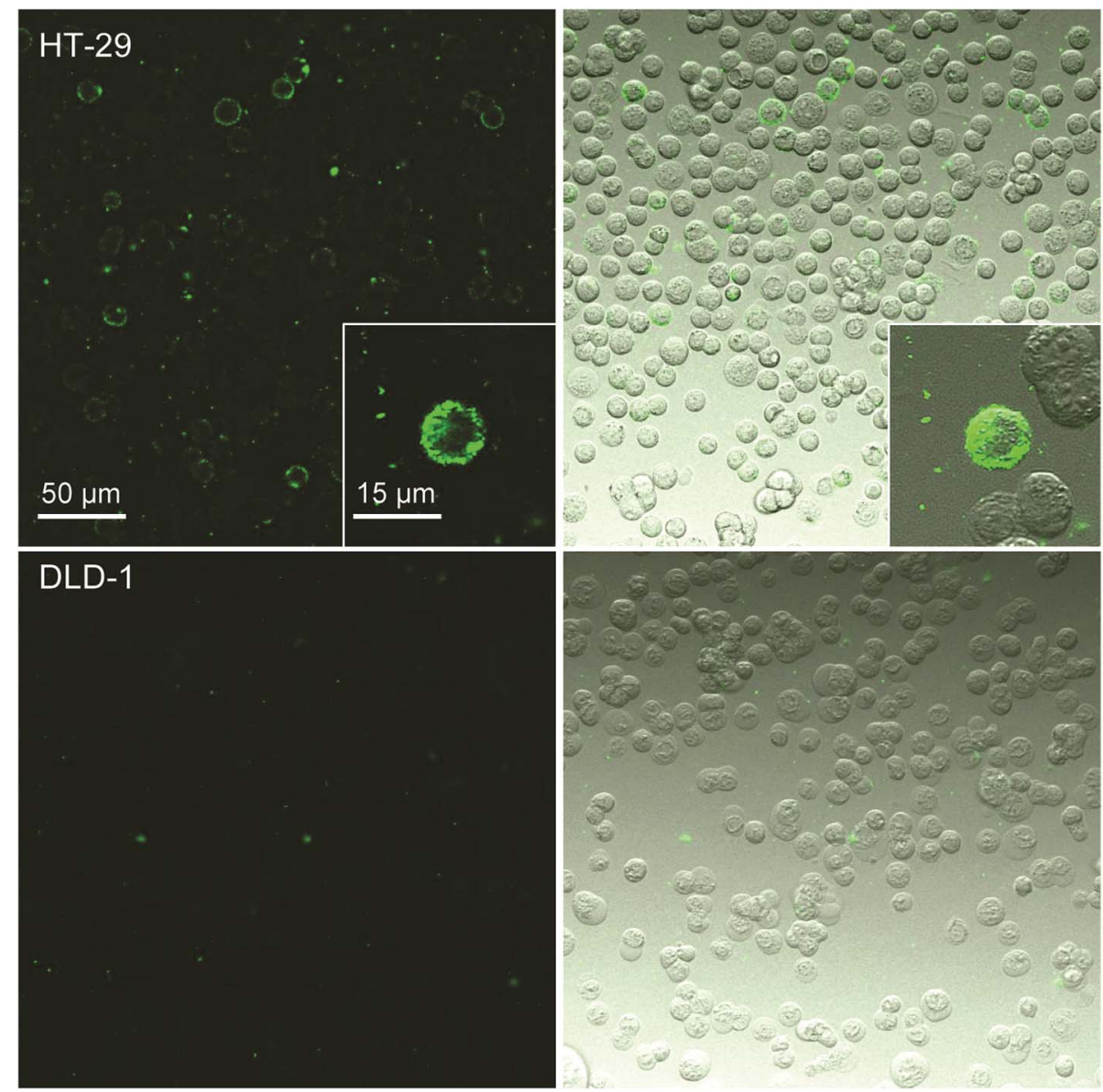

Fig. 4 Fluorescence microscopy experiments with $\mathrm{SiO}_{2}-$ pHPMA-M75 nanoparticles show specific interaction with $\mathrm{HT}-29$ cells and no interaction with DLD-1 cells (left - fluorescence mode; right - overlay of fluorescence and optical mode). 

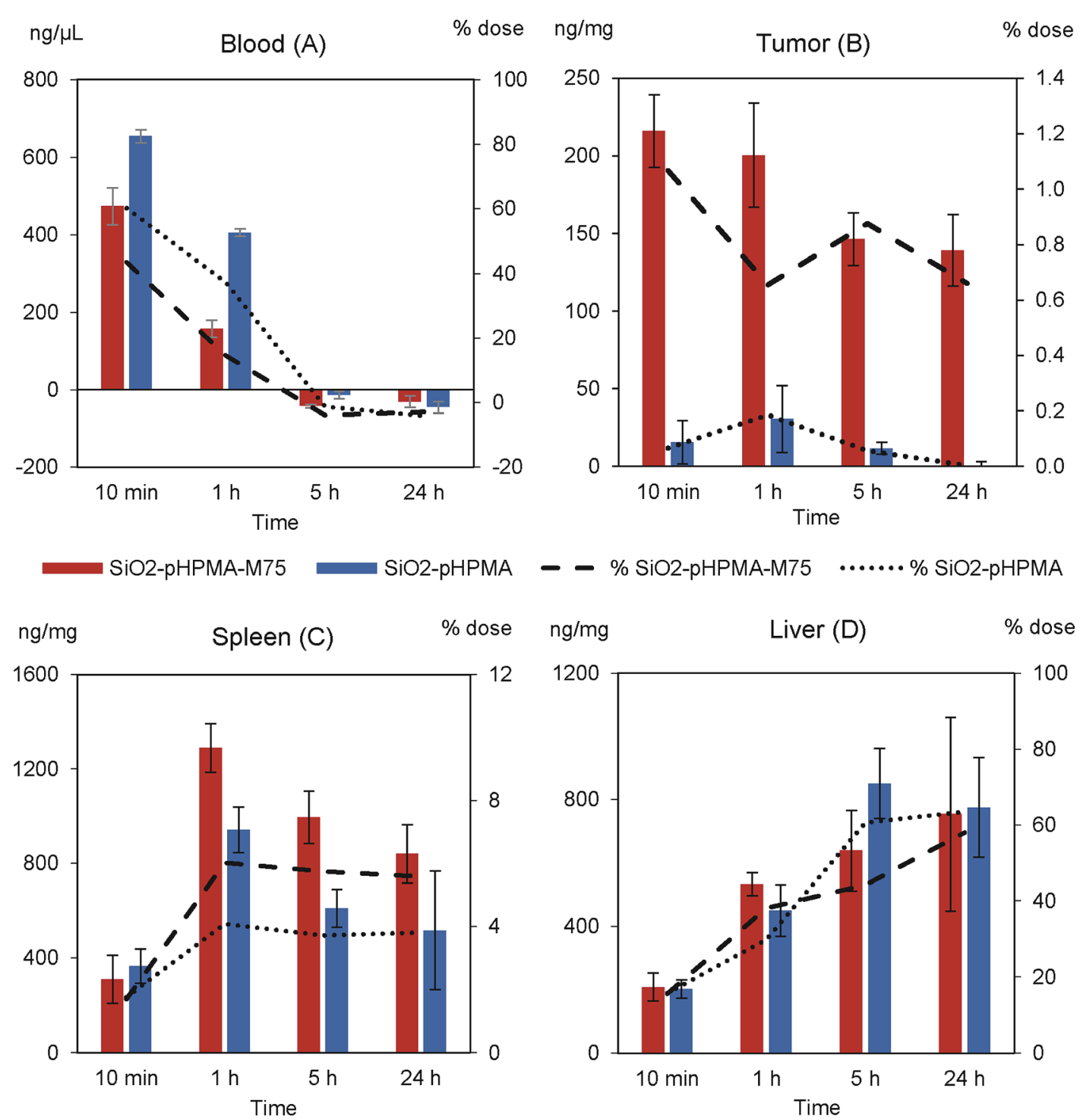

Fig. 5 In vivo study I (dose $75 \mathrm{mg} \mathrm{kg}^{-1}$ ). Primary vertical axis (columns) shows nanoparticle concentration in (A) blood, (B) tumour, (C) spleen and (D) liver in time. Secondary vertical axis (lines) shows the percentage of the total administered dose. Red/dashed line $-\mathrm{SiO} 2-\mathrm{pHPMA}-\mathrm{M} 75$; blue/ dotted line $-\mathrm{SiO}_{2}-$ pHPMA.

M75) adhered only to the HT-29 cells and not to DLD-1 cells. The uneven distribution of the nanoparticles on the cell surface can be due to the variable level of CA IX expression on the surface of the individual cells. Nanoparticles without the specific antibody did not interact with the HT-29 cells as shown in ESI 1. $\dagger$

\section{In vivo behaviour}

The nanoparticle biodistribution and specific accumulation in tumour tissue was investigated in athymic NU/NU nude mice bearing HT-29 tumours in two separated in vivo studies. First (in vivo study I), we focused on the circulation times and blood clearance of the stealth $\mathrm{SiO}_{2}$-pHPMA nanoparticles and the tumour targeting of the $\mathrm{SiO}_{2}-$ pHPMA-M75 nanoparticles using an initial dose of $75 \mathrm{mg} \mathrm{kg}^{-1}$, which was based on typical values that can be tolerated by the animals.
Both types of nanoparticles were detected in the blood of all mice even after 1 hour from the nanoparticle administration (Fig. 5A), which can be considered as significantly prolonged circulation in comparison to other types of particles. ${ }^{3,39}$ This finding opens up new possibilities for the development of silica-pHPMA drug-delivery particles.

Antibody-modified nanoparticles ( $\left.\mathrm{SiO}_{2}-\mathrm{pHPMA}-\mathrm{M} 75\right)$ were removed slightly faster than nanoparticles without the antibody ( $\mathrm{SiO}_{2}$-pHPMA), which can be attributed to the fact that the antibody may act in a similar way as opsonin, and enhance macrophage phagocytosis ${ }^{6,40}$ (the random orientation of the antibodies on the nanoparticle surface leads to the exposure of the Fc fragments and their subsequent recognition by the macrophage membrane receptors).

The most important finding concerns the efficiency of the tumour targeting. Actively targeted $\mathrm{SiO}_{2}-$ pHPMA-M75 

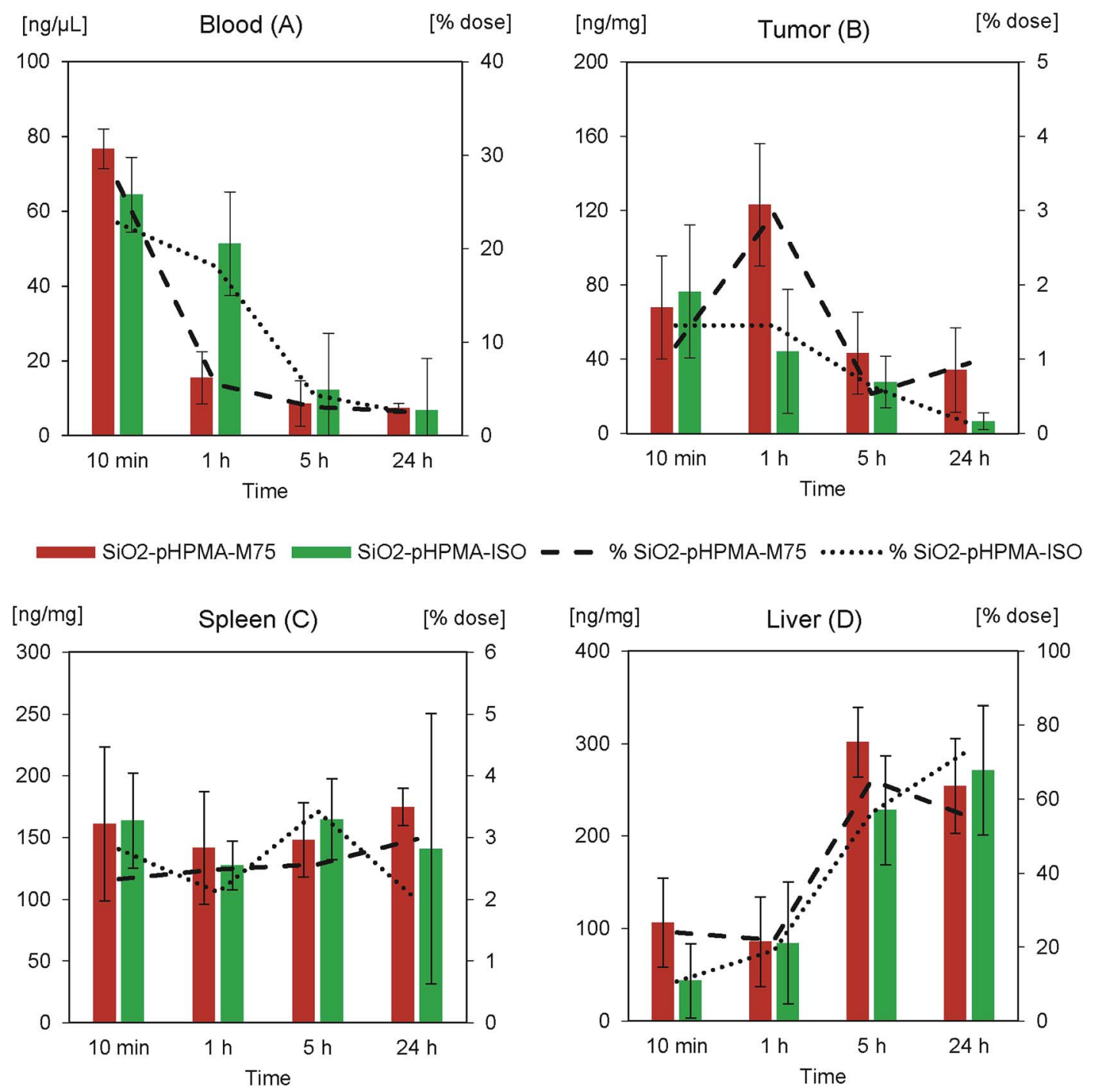

Fig. 6 In vivo study II (dose $20 \mathrm{mg} \mathrm{kg}^{-1}$ ). Primary vertical axis (columns) shows nanoparticle concentration in (A) blood, (B) tumour, (C) spleen and (D) liver in time. Secondary vertical axis (lines) shows the percentage of the total administered dose. Red/dashed line $-\mathrm{SiO}_{2}-\mathrm{pHPMA}-\mathrm{M} 75$; green/ dotted line $-\mathrm{SiO}_{2}-$ pHPMA-ISO.

nanoparticles accumulate in the tumour at tenfold higher concentration than the non-targeted ones (Fig. 5B) and reach the maximum measured concentration already within 10 minutes after the administration. Moreover, these nanoparticles are significantly retained in the tumour tissue even after 24 hours, compared to nanoparticles without the antibody ( $\mathrm{SiO}_{2}$-pHPMA). In case of drug delivery application, this should provide enough time for the drug release or even in situ drug production, if the particles are loaded with the drug precursors.

High concentrations of nanoparticles were, as expected, detected in the spleen (Fig. 5C) and liver (Fig. 5D), organs of the Reticulo-Endothelial System (RES). The concentration in these organs increases in time, where in the case of the spleen it can be concluded that nanoparticles modified with the antibody are retained more. The overall nanoparticle distribution together with the fact that the maximum concentration in the tumour was reached within 10 minutes after the administration, indicates that the administered nanoparticle dose was probably too high and the binding sites in the tumour were saturated while an excess of nanoparticles remained in circulation and was available to the other organs. Hence, it was hypothesised that by decreasing the dose, a more favourable tumour : RES ratio should be obtained.

In order to confirm this hypothesis and to better understand the dose effect on the nanoparticle accumulation, the in vivo study II was carried out. Since the stealth effect of pHPMA nanoparticle coating was already confirmed in in vivo study I, nanoparticles with an irrelevant IgG $2 \mathrm{~b}$ isotypic antibody $\left(\mathrm{SiO}_{2}{ }^{-}\right.$ pHPMA-ISO) were chosen as a negative control, in order to eliminate possible effects of the particle surface chemistry. The administered nanoparticle dose in study II was $20 \mathrm{mg} \mathrm{kg}^{-1}$, which is approximately 4 times less than in study I but still enables reliable fluorescence detection of the nanoparticles on the background of autofluorescent tissues. The nanoparticle 
concentration in the blood (Fig. 6A) decreased faster than in the case of the higher nanoparticle dose. This can be attributed to the macrophage phagocytic capacity and kinetics.

The maximum concentration of the specifically targeted $\mathrm{SiO}_{2}$-pHPMA-M75 nanoparticles in the tumour was measured at 1 hour from the administration of the lower dose (Fig. 6B). This indicates a connection between the dose and the tumour accumulation kinetics. The maximum concentration of nanoparticles in the tumour relative to the dose was approximately $3 \times$ higher in comparison with in vivo study I. An interesting and a very positive result is that by reducing the dose, the tumour : RES ratio (measured 1 hour after administration) was improved from approx. $1: 40$ (in vivo study I) to $3: 20$ (in vivo study II). Hence, exploiting differences in the tumour accumulation and macrophage uptake kinetics offers possibilities for further optimization of the nanoparticle targeting.

Nanoparticles without specific targeting ( $\left.\mathrm{SiO}_{2}-\mathrm{pHPMA}-\mathrm{ISO}\right)$ do not significantly accumulate in the tumour tissue, however their concentration in the $10^{\text {th }}$ minute after the administration was approximately $2 \times$ higher than in the case of $\mathrm{SiO}_{2}-$ pHPMA nanoparticles in the first in vivo study. This might be attributed to the presence of protein molecules on the nanoparticle surface, which increases their zeta potential and thus can lead to enhanced nanoparticle extravasation or retention in the tumour tissue in comparison to nanoparticles without the antibody $\left(\mathrm{SiO}_{2}-\right.$ pHPMA $) .{ }^{41} \mathrm{SiO}_{2}-$ pHPMA-ISO nanoparticles were not significantly retained and their concentration in the tumour decreased proportionally with their concentration in the blood.

The nanoparticle accumulation in the spleen (Fig. 6C) shows lower differences between the used nanoparticle types than in the first study, which is due to the higher surface similarity (both types bear antibody molecules on the surface). The total nanoparticle concentration in the liver (Fig. 6D) after 24 hours reaches approximately $60 \%$ of the administered dose, which is the same as in the first study.

\section{Conclusion}

For the first time, fluorescent silica nanoparticles $(170 \mathrm{~nm})$ coated by a covalently attached polymeric chain based on amino-reactive multivalent $\operatorname{poly}(N$-(2-hydroxypropyl)methacrylamide) (pHPMA) and an antibody IgG M75 coupled via the polymer were prepared and characterized in a series of physicochemical, in vitro and in vivo tests. The amount of the polymer and the antibody, determined by amino acid analysis, was established as $3.6 \mathrm{wt} \%$ and $1.0 \mathrm{wt} \%$, respectively. Nanoparticle stability in physiological media was established by DLS measurements.

ELISA-like tests revealed specific interaction between nanoparticles bearing the IgG M75 antibody and an antigen comprising of the proteoglycan domain of Carbonic Anhydrase IX (CA IX) in fusion with the Maltose Binding Protein (PG-MBP). Further in vitro characterization employing flow cytometry demonstrated that $\mathrm{SiO}_{2}-$ pHPMA-M75 nanoparticles were able to bind selectively to the tumour cells HT-29, which express CA IX.
In vivo study carried out on athymic NU/NU nude mice bearing HT-29 tumours showed that nanoparticles coated with poly( $N$-(2-hydroxypropyl)methacrylamide) could circulate in the blood longer than 60 minutes, which indicates the stealth effect of pHPMA and increases the possibility of reaching the target tissue. Further, it was shown that actively targeted $\mathrm{SiO}_{2}-$ pHPMA-M75 nanoparticles accumulated in the tumour at tenfold higher concentration compared to $\mathrm{SiO}_{2}-$ pHPMA nanoparticles and were retained in the tumour tissue even 24 hours after the administration of a $75 \mathrm{mg} \mathrm{kg}^{-1}$ dose. The study of the nanoparticles with irrelevant isotypic antibody $\left(\mathrm{SiO}_{2}-\mathrm{pHPMA}-\right.$ ISO) administered at $20 \mathrm{mg} \mathrm{kg}^{-1}$ dose indicates that the presence of the protein molecule on the nanoparticle surface enhanced nanoparticle extravasation in the fenestrated tumour vasculature in comparison to $\mathrm{SiO}_{2}$-pHPMA nanoparticles, but these nanoparticles were not retained in the tissue due to the absence of a specific antibody.

It was shown that the lowering of the nanoparticle dose can lead to a change in the tumour accumulation kinetics. While the high dose caused a fast saturation of the tumour tissue binding sites (the maximum concentration was measured in the $10^{\text {th }}$ minute), the administration of the lower dose lead to the maximum concentration at 1 hour after administration. Consequently, the nanoparticle dose reduction resulted in a $6 \times$ improvement of the tumour: RES ratio. In summary, silica nanoparticles coated with pHPMA and IgG M75 were shown to be a promising tumour targeting system with potential for further functionality enhancement (e.g. drug delivery).

\section{Methods}

\section{Chemicals}

The following chemicals were used for the synthesis, modification and characterization of the nanoparticles: (3-aminopropyl)triethoxysilane (APTES), 3-sulfanylpropanoic acid, $\beta$ alanine, albumin from bovine serum (BSA), ammonium hydroxide (28-30\%), fluorescein 5(6)-isothiocyanate (FITC), methanol, $o$-phthalaldehyde, phosphate buffered saline (PBS) tablets, sodium acetate, tetraethyl orthosilicate (TEOS) and triethylamine from Sigma-Aldrich, 1-aminopropan-2-ol from TCI Europe N.V., propidium iodide from Fluka and ethanol for UV, sodium chloride and hydrochloric acid from Penta. The isotypic IgG $2 \mathrm{~b}$ antibody was purchased from Exbio Praha, a.s. and goat anti mouse IgG-FITC (GAM-FITC) antibody was purchased from Jackson Immunoresearch Laboratories. Water was produced by a demineralized water generator Aqual 25 . Polymer p(HPMA-co-Ma- $\beta$ Ala-TT) (pHPMA) $\left(M_{\mathrm{w}}=44000\right)$ with amino-reactive thiazolidine-2-thione (TT) groups $(6.8 \%)$ was prepared by reversible addition-fragmentation chain transfer (RAFT) polymerization as described earlier. ${ }^{42}$ The synthesis and characterisation of PHPMA is described in ESI $2 . \dagger$ The monoclonal antibody IgG M75 (M75) ${ }^{43}$ and the proteoglycan (PG) domain of Carbonic Anhydrase IX (CA IX) in fusion with the Maltose Binding Protein (PG-MBP) were provided by the Laboratory of Structural Biology, Institute of Molecular Genetics of the Czech Academy of Sciences, Prague, Czech Republic. 


\section{Cells and media}

The cell line HT-29 (human epithelial; tissue: colon; disease: colorectal adenocarcinoma; ATCC) and the cell line DLD-1 (human epithelial; tissue: colon; disease: Dukes' type C, colorectal adenocarcinoma; ATCC) were grown in DMEM (D6429, Sigma-Aldrich) and RPMI-1640 medium (R8758, SigmaAldrich), respectively. Both media were supplemented with $10 \%$ heat inactivated FBS (10270-106, Invitrogen) and 1\% mix of antibiotics and antimycotics anti-anti (15240, Invitrogen). The cells were cultured at $37{ }^{\circ} \mathrm{C}$ in a $5 \% \mathrm{CO}_{2}$ atmosphere until 70$80 \%$ confluency.

\section{Nanoparticle synthesis}

Synthesis of fluorescently labeled amino-silica nanoparticles was carried out according to the Stöber method. ${ }^{\mathbf{4 4}}$ Briefly, $7.7 \mathrm{~mL}$ of ammonium hydroxide was mixed with $100 \mathrm{~mL}$ of ethanol. The mixture was heated to $30{ }^{\circ} \mathrm{C}$ under continuous stirring with a magnetic stirrer in a two-neck round flask equipped with a reflux condenser. After reaching $30{ }^{\circ} \mathrm{C}$, the solution was equilibrated for $30 \mathrm{~min}$ and subsequently $3 \mathrm{~mL}$ of TEOS was added under continuous stirring (500 rpm). Simultaneously, $3 \mathrm{~mL}$ of FITC solution (20 $\mathrm{mg}$ of FITC and $123 \mathrm{mg}$ of APTES in $10 \mathrm{~g}$ of ethanol, stirred for $48 \mathrm{~h}$ in a dark at room temperature) was added to the mixture. ${ }^{45}$ The condensation reaction was allowed to proceed for $22 \mathrm{~h}$ at a constant temperature $30{ }^{\circ} \mathrm{C}$. The colloidal dispersion was then cooled down to room temperature and cleaned by repeated centrifugation (10 min at $10000 \mathrm{~g}$ ) and washing (3-times with ethanol) and resuspended in demineralized water. The prepared nanoparticles were dialyzed against a sodium chloride solution $(0.1 \mathrm{M}$ in water) for 2 days in dark to remove unbound FITC and unreacted TEOS, and then against demineralized water for one more day in dark to remove all salts and thus prevent nanoparticle aggregation. The dispersion was then centrifuged and re-suspended in ethanol to a final concentration of $10 \mathrm{mg} \mathrm{mL}^{-1}$. Further nanoparticle modification in order to introduce reactive amino groups was done by a reaction of APTES solution ( $3 \mathrm{~mL}$ of ethanol, $50 \mu \mathrm{L}$ of demineralized water, $63 \mu \mathrm{L}$ of APTES adjusted to $\mathrm{pH} \approx 2$ with $\mathrm{HCl}$ and stirred for 15 minutes) with previously prepared nanoparticles in ratio $0.2 \mathrm{~mL}$ of APTES solution to $5 \mathrm{~mL}$ of nanoparticle suspension. The reaction was carried out in a dark at room temperature for 24 hours. After the reaction, triethylamine was added to the reaction container to obtain $\mathrm{pH}$ 8.0, then the nanoparticles were washed 3-times with ethanol (centrifugation at $10000 \mathrm{~g}$ for $10 \mathrm{~min}$ ) and re-suspended in ethanol $\left(20 \mathrm{mg} \mathrm{mL}^{-1}\right)$ for further use. The sample was stored in the dark.

\section{Nanoparticle surface modification}

PHPMA modified nanoparticles. For the reaction, the nanoparticles prepared as described above were used. $1 \mathrm{~mL}$ of nanoparticle suspension $\left(20 \mathrm{mg} \mathrm{mL}^{-1}\right)$ was mixed with $1 \mathrm{~mL}$ of amino-reactive pHPMA-based copolymer solution $\left(2 \mathrm{mg} \mathrm{mL} \mathrm{m}^{-1}\right.$ in ethanol) and stirred at room temperature for 10 minutes. Scheme 1 shows the principle of the reaction between amino-
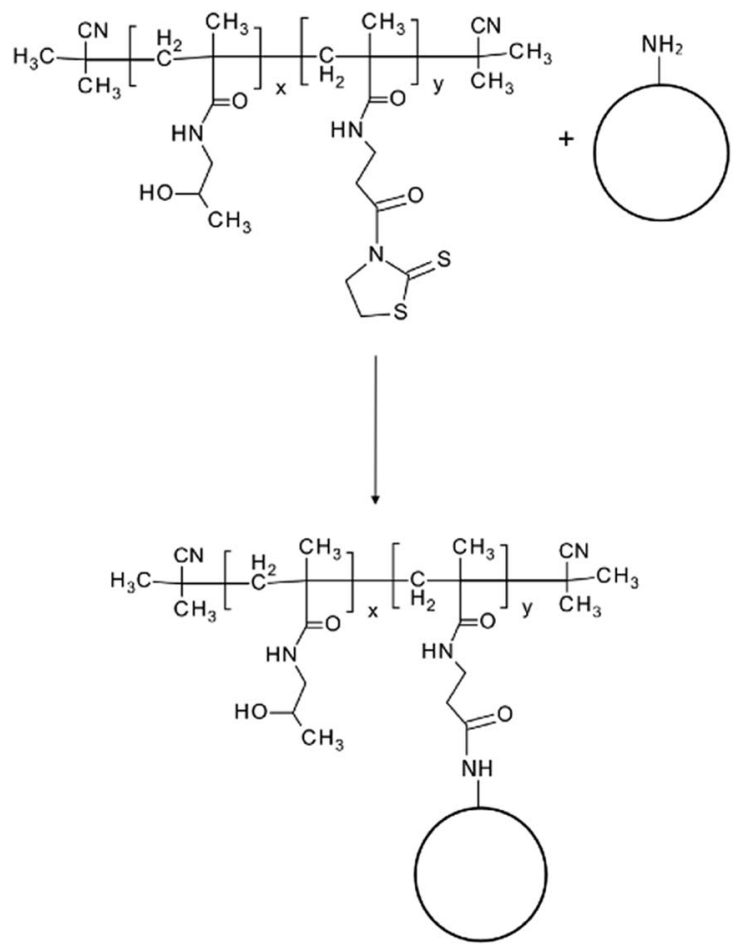

Scheme 1 Illustration of reaction between amino-group bearing object and amino-reactive $T$ group of pHPMA. $X=93.2, Y=6.8$.

reactive thiazolidine-2-thione (TT) group in pHPMA and an amino-group bearing object (e.g. $\mathrm{SiO}_{2}-\mathrm{NH}_{2}$ nanoparticle or amino-group of lysine present in the antibody structure). To cleave all unreacted TT groups, $10 \mu \mathrm{L}$ of 1-amino-2-propanol was added and the suspension was stirred for 15 more minutes. Then the sample was washed 3-times with PBS and stored in $1 \%$ BSA/PBS in the fridge $\left(4{ }^{\circ} \mathrm{C}\right)$.

Antibody and pHPMA modified nanoparticles. For this reaction, the $\mathrm{SiO}_{2}-\mathrm{NH}_{2}$ nanoparticles prepared according to the procedure described above were used. $1 \mathrm{~mL}$ of nanoparticle suspension $\left(20 \mathrm{mg} \mathrm{mL}^{-1}\right)$ was mixed with $1 \mathrm{~mL}$ of amino-reactive pHPMA-based copolymer solution $\left(2 \mathrm{mg} \mathrm{mL}^{-1}\right.$ in ethanol). The reaction between amino-groups present on the particle surface and pHPMA-based copolymer proceeded for 10 minutes at room temperature under continuous stirring. Then the particles were washed 2-times with PBS by repeated centrifugation $(5 \mathrm{~min}$, $10000 \mathrm{~g}$ ) and re-suspended in $1 \mathrm{~mL}$ of PBS. In the next step, $0.67 \mathrm{mg}$ of the antibody IgG M75 or the isotypic antibody IgG $2 \mathrm{~b}$ was added in a PBS solution. The amount of the antibody was estimated based on previous experience with antibody coupling to nanoparticles. ${ }^{46}$ The coupling reaction of IgG M75 with available amino-reactive TT groups from pHPMA that were not consumed by the polymer coupling to the silica nanoparticles was carried out under continuous stirring at room temperature for 20 minutes. Then, $1 \mu \mathrm{L}$ of 1-amino-2-propanol was added and the suspension was stirred for 10 more minutes to complete the aminolysis of the residual amino-reactive TT groups. In the final step the nanoparticles with covalently bound IgG M75 were washed 3-times with PBS, re-suspended in $1 \mathrm{~mL}$ of $1 \% \mathrm{BSA} / \mathrm{PBS}$ (final concentration $\left.20 \mathrm{mg} \mathrm{mL}{ }^{-1}\right)$, and stored in the fridge $\left(4^{\circ} \mathrm{C}\right)$. 
pHPMA and antibody quantification. The amount of pHPMA and antibody attached to the nanoparticles was quantified via amino acid analysis. For the experiment, $4.5 \mathrm{mg}$ of prepared nanoparticles were freeze-dried and subsequently pHPMA and antibody bound to their surface were hydrolyzed $(500 \mu \mathrm{L}$ of $6 \mathrm{M}$ $\mathrm{HCl}, 18 \mathrm{~h}, 115{ }^{\circ} \mathrm{C}$ in a sealed ampule). The amino acid analysis of the hydrolyzed sample was performed on a HPLC system (Shimadzu, Japan) equipped with a fluorescence detector (Shimadzu, Japan) and reversed-phase Chromolith Performance RP-18e column, $100 \times 4.6 \mathrm{~mm}$ (Merck, Germany), using precolumn derivatization with $o$-phthalaldehyde (OPA) and 3-sulfanylpropanoic acid (excitation at $229 \mathrm{~nm}$, emission at $450 \mathrm{~nm}$ ) and a gradient elution of $0-100 \%$ solvent $B$ over $35 \mathrm{~min}$ at a flow rate of $1.0 \mathrm{~mL} \mathrm{~min}^{-1}$ (solvent A: $0.05 \mathrm{M}$ sodium acetate buffer, pH 6.5; solvent B: $300 \mathrm{~mL}$ of $0.17 \mathrm{M}$ sodium acetate and $700 \mathrm{~mL}$ of methanol). The amount of pHPMA was calculated according to the calibration of $\beta$-alanine, which is present in the hydrolyzed polymer in a known quantity $\left(0.451 \mathrm{mmol} \mathrm{g}^{-1}\right.$ polymer $)$. The amount of antibody was calculated according to the calibration prepared from the free antibody solution hydrolyzed and derivatized using the same protocol as described above.

\section{Physico-chemical characterisation of nanoparticles}

The morphology of the prepared silica nanoparticles was examined by Transmission Electron Microscopy (TEM; JeolJEM-1010). The particle size distribution and the zeta potential were determined by Dynamic Light Scattering (DLS, Zetasizer Nano-ZS). For the DLS measurement, the nanoparticles were dispersed in demineralized water to a final concentration of $0.5 \mathrm{mg} \mathrm{mL}^{-1}$ and each measurement was carried out in triplicate, at $25^{\circ} \mathrm{C}$ and at a detector angle of $173^{\circ}$.

\section{In vitro characterisation}

ELISA-like test. ELISA-like experiment was performed to prove the presence and functionality of the monoclonal antibody IgG M75 covalently bound to the nanoparticle surface using fluorescent well-plate reader Tecan Infinite M200 with Magellan software. The ELISA-like test is much easier and faster than the usually employed sandwich ELISA. Because the monoclonal antibody IgG M75 is covalently bound to the fluorescent nanoparticles, there is no need to use the secondary antibody, which significantly lowers the time demands (and by reducing the number of experimental steps, also decreases the possibility of errors occurring).

$100 \mu \mathrm{L}$ of the PG-domain fused with the Maltose Binding Protein (PG-MBP) solution $\left(2.5 \mu \mathrm{g} \mathrm{mL} \mathrm{m}^{-1}\right)$ was added to the desired number of wells in a polystyrene 96-well plate. As a control, the MBP solution of the same concentration and volume was used in the same well-plate. The well-plate was stored in the fridge $\left(4{ }^{\circ} \mathrm{C}\right)$ overnight to achieve sufficient adhesion of the protein to the surface of the well-plate. After a 5-times repeated wash with $200 \mu \mathrm{L}$ of PBS, a solution of $1 \%$ BSA in PBS was added $(200 \mu \mathrm{L})$ to block the free, unmodified surface of the wells (1 hour incubation, room temperature). Each well was then washed 3-times with $200 \mu \mathrm{L}$ of PBS. In the next step, the nanoparticle suspensions $(100 \mu \mathrm{L}$ of
$\mathrm{SiO}_{2}$-pHPMA, $\mathrm{SiO}_{2}$-pHPMA-M75 and $\mathrm{SiO}_{2}$-pHPMA-ISO; each in a concentration series $1 \mathrm{mg} \mathrm{mL}^{-1}, 0.5 \mathrm{mg} \mathrm{mL}^{-1}, 0.25 \mathrm{mg} \mathrm{mL}^{-1}$, $0.125 \mathrm{mg} \mathrm{mL}^{-1}$ and $0.0625 \mathrm{mg} \mathrm{mL}^{-1}$ ) were added and incubated for one hour at room temperature. Then, all wells were washed 5times with $200 \mu \mathrm{L}$ of PBS and the fluorescence was analyzed using a fluorescent well-plate reader. The analysis was performed via gain optimal mode (excitation $488 \mathrm{~nm}$, emission $516 \mathrm{~nm}$ ), which assigns the maximum numerical value to the well with the highest fluorescence intensity and then calculates the relative values of fluorescence intensity for all other wells.

Flow cytometry. The experiment was carried out to confirm the interaction between the specific antibody-modified nanoparticles $\left(\mathrm{SiO}_{2}\right.$-pHPMA-M75) and HT-29 cells (expressing CA IX) and exclude the possibility of non-specific interactions (nanoparticles without the specific antibody: $\mathrm{SiO}_{2}$-pHPMA and $\mathrm{SiO}_{2}-$ pHPMA-ISO). As a control, the DLD-1 cell line (not expressing CA IX) was used.

The samples for flow cytometry were prepared in a 96-well plate. 300000 cells (HT-29 or DLD-1) were added to each well. Then the antibody IgG M75 $\left(15 \mu \mathrm{L}, 14.4 \mu \mathrm{g} \mathrm{mL}^{-1}\right)$ was added to the wells for the positive control (tests the CA IX presence) - one well per each cell type. After 25 minutes of incubation on ice (to prevent the internalization of the antibody) the cells were washed twice with $200 \mu \mathrm{L}$ of $1 \%$ BSA/PBS by repeated centrifugation (5 min, 280g). Then the fluorescent secondary antibody (goat anti mouse IgG antibody conjugated with FITC (GAMFITC); $15 \mu \mathrm{L}, 20 \mu \mathrm{g} \mathrm{mL}{ }^{-1}$ ) was added to the positive control wells, where IgG M75 was used previously. The secondary antibody was also added to one more well per each cell type as a negative control. In the same step, nanoparticle dispersions were added to the other wells $(15 \mu \mathrm{L} ; 3.75 \mu \mathrm{g})$. After 20 minutes of incubation on ice, the cells were washed twice with $200 \mu \mathrm{L}$ of $1 \% \mathrm{BSA} / \mathrm{PBS}$ by repeated centrifugation $(5 \mathrm{~min}, 280 g)$. Then, propidium iodide solution in $1 \%$ BSA/PBS $\left(0.5 \mu \mathrm{g} \mathrm{mL} \mathrm{m}^{-1}\right)$ was added (propidium iodide intercalates to the DNA of dead cells), the samples were transferred to plastic test tubes and subsequently analyzed.

The evaluation of the experiment was performed using the Becton Dickinson FACS Aria II flow cytometer. The fluorescence of 10000 events was measured, using the laser excitation wavelength of $488 \mathrm{~nm}$. Emission was read by a detector with a set of two dichroic mirrors 530/30 Band Pass and 502 Long Pass. The raw data were evaluated by software FlowJo 7.6.1 (Tree Star, Inc.) and presented in the form of histograms. The $y$-axis shows the number of the cells while the $x$-axis represents the intensity of fluorescence emitted by the cell (FITC channel).

Fluorescence microscopy. For the purpose of fluorescence microscopy, $20 \mu \mathrm{L}$ of 400000 cells (HT-29 or DLD-1) in ice-cold $1 \%$ BSA in PBS was added to the each well of a 96-well plate. Then, $20 \mu \mathrm{L}$ of nanoparticles $\left(\mathrm{SiO}_{2}-\mathrm{pHPMA}-\mathrm{M} 75, \mathrm{SiO}_{2}\right.$-pHPMAISO and $\mathrm{SiO}_{2}$-pHPMA, $1 \mathrm{mg} \mathrm{mL}{ }^{-1}$ ) in ice-cold $1 \%$ BSA in PBS was added to the wells and incubated with the cells for 1 hour. After the incubation, samples were centrifuged $(250 \mathrm{~g}, 3 \mathrm{~min})$ and re-suspended in $500 \mu \mathrm{L}$ of ice-cold $1 \%$ BSA in PBS. The samples were analyzed using Olympus Fluoview FV1000 confocal system (488 $\mathrm{nm}$ laser excitation wavelength). 


\section{In vivo characterisation}

Animal study. Athymic NU/NU nude mice were obtained from Charles River. Mice were used at 9 to 15 weeks of age and kept in the conventional animal facility of Institute of Microbiology of ASCR, v.v.i. Mice were regularly screened for MHV and other pathogens according to FELASA. All experiments were approved by the Animal Welfare Committee at the Institute of Microbiology of ASCR, v.v.i. After one week of acclimatization, mice weighting on average $25 \mathrm{~g}$ were subcutaneously injected with $4 \times 10^{6}$ HT-29 cells and the tumour growth lasted for 14 days. The in vivo testing was carried out in two independent studies. The study I explored the stealth effect of pHPMA particle coating ( $\mathrm{SiO}_{2}-\mathrm{pHPMA}$ nanoparticles) on the blood circulation time and the capability of antibody modified stealth nanoparticles $\left(\mathrm{SiO}_{2}-\mathrm{pHPMA}-\mathrm{M} 75\right)$ to reach the tumour and accumulate in the tumour tissue. In study I, three mice per each time point were injected with $75 \mathrm{mg} \mathrm{kg}^{-1}$ nanoparticle dose (1.96 $\mathrm{mg}$ in $300 \mu \mathrm{L}$ of $1 \% \mathrm{BSA} / \mathrm{PBS}$ ) into the tail vein. As a control, three mice were injected with $300 \mu \mathrm{L}$ of $1 \%$ BSA/PBS.

The in vivo study II was performed after the successful study I experiments and explored the effect of lower nanoparticle dose on the tumour accumulation. For the experiments, the nanoparticles with the specific antibody $\left(\mathrm{SiO}_{2}-\mathrm{pHPMA}-\mathrm{M} 75\right)$ and the nanoparticles with the irrelevant isotypic antibody IgG $2 \mathrm{~b}\left(\mathrm{SiO}_{2}-\right.$ pHPMA-ISO) were used. Three mice per each time point were injected with $20 \mathrm{mg} \mathrm{kg}^{-1}$ nanoparticle dose $(0.65 \mathrm{mg}$ in $300 \mu \mathrm{L}$ of $1 \% \mathrm{BSA} / \mathrm{PBS}$ ) into the tail vein. As a control, three mice were injected with $300 \mu \mathrm{L}$ of $1 \%$ BSA/PBS. No clinical observations were noted during both studies.

After the required time (10 $\mathrm{min}, 1 \mathrm{~h}, 5 \mathrm{~h}, 24 \mathrm{~h}$ ) the animals were euthanized and the tissues (liver, spleen, brain, and tumour) were collected, weighted and homogenized in Lyzing Matrix A $2 \mathrm{~mL}$ Tube (MP Biomedicals) using FastPrep 24 instrument (MP Biomedicals). The blood samples were collected into the heparinized tubes. All tissue and blood samples were stored on ice until the analysis.

Fluorescence measurement. Before the measurement, the homogenized tissue samples were centrifuged (2 min, 2000g). $80 \mu \mathrm{L}$ of the resulting supernatants (or blood) was pipetted into the wells of a 96 well-plate (Nunclon black, Sigma-Aldrich), already containing $100 \mu \mathrm{L}$ of PBS in each well. For each type of the tissue a separate well-plate containing nanoparticle calibration was used $(100 \mu \mathrm{L}$ of nanoparticle dispersions in PBS and $80 \mu \mathrm{L}$ of the tissue homogenates from the control group mice). Before the measurement, all well-plates were gently mixed. The fluorescence intensity was measured using Tecan Infinite 200 with i-Control software (excitation $488 \mathrm{~nm}$, emission $516 \mathrm{~nm}$ ). The final concentrations were calculated in accordance to the weight of each organ. The nanoparticle concentration in brain was measured as a control and was zero in all cases.

\section{Conflicts of interest}

There are no conflicts to declare.

\section{Acknowledgements}

The authors would like to thank Milan Fábry and Irena Sieglová (Institute of Molecular Genetics of the Czech Academy of Sciences, 14200 Prague 4, Czech Republic) for providing PGMBP and MBP. Authors also thank Nina Sarvašová and Ondřej Kašpar for the illustrations. In vivo studies were kindly supported by Sotio, a.s. D.L. and M.M. were support by Specific University Research (MSMT No 21-SVV/2018). F.S. was supported by the Agency for Healthcare Research (AZV NV1634342A). V.K. would like to acknowledge Institutional Support (RVO 68378050). M.P. and R.P. were supported by the Czech Science Foundation (GACR 16-17207S).

\section{References}

1 D. E. Owens III and N. A. Peppas, Int. J. Pharm., 2006, 307, 93102.

2 S. M. Moghimi and J. Szebeni, Prog. Lipid Res., 2003, 42, 463478.

3 L. Illum, S. Davis, R. Müller, E. Mak and P. West, Life Sci., 1987, 40, 367-374.

4 M. A. Dobrovolskaia, P. Aggarwal, J. B. Hall and S. E. McNeil, Mol. Pharm., 2008, 5, 487-495.

5 S. Parveen and S. K. Sahoo, Eur. J. Pharmacol., 2011, 670, 372383.

6 P. Aggarwal, J. B. Hall, C. B. McLeland, M. A. Dobrovolskaia and S. E. McNeil, Adv. Drug Delivery Rev., 2009, 61, 428-437.

7 C. D. Walkey, J. B. Olsen, H. Guo, A. Emili and W. C. Chan, J. Am. Chem. Soc., 2012, 134, 2139-2147.

8 P. Decuzzi, B. Godin, T. Tanaka, S.-Y. Lee, C. Chiappini, X. Liu and M. Ferrari, J. Controlled Release, 2010, 141, 320327.

9 S. M. Moghimi, A. C. Hunter and J. C. Murray, Pharmacogn. Rev., 2001, 53, 283-318.

10 J. Cheng, B. A. Teply, I. Sherifi, J. Sung, G. Luther, F. X. Gu, E. Levy-Nissenbaum, A. F. Radovic-Moreno, R. Langer and O. C. Farokhzad, Biomaterials, 2007, 28, 869-876.

11 M. Hans and A. Lowman, Curr. Opin. Solid State Mater. Sci., 2002, 6, 319-327.

12 K. Knop, R. Hoogenboom, D. Fischer and U. S. Schubert, Angew. Chem., Int. Ed., 2010, 49, 6288-6308.

13 D. Calvo, M. Jesús and D.-H. Lee, Rev. Esp. Cardiol., 2006, 59, 399-400.

14 J. Szebeni, Toxicology, 2005, 216, 106-121.

15 A. Chanan-Khan, J. Szebeni, S. Savay, L. Liebes, N. Rafique, C. Alving and F. Muggia, Ann. Oncol., 2003, 14, 1430-1437.

16 J. Szebeni, L. Baranyi, S. Savay, J. Milosevits, R. Bunger, P. Laverman, J. Metselaar, G. Storm, A. Chanan-Khan and L. Liebes, J. Liposome Res., 2002, 12, 165-172.

17 R. Duncan, Nat. Rev. Cancer, 2006, 6, 688.

18 T. Lammers, R. Kühnlein, M. Kissel, V. Subr, T. Etrych, R. Pola, M. Pechar, K. Ulbrich, G. Storm and P. Huber, J. Controlled Release, 2005, 110, 103-118.

19 S. Kunjachan, F. Gremse, B. Theek, P. Koczera, R. Pola, M. Pechar, T. Etrych, K. Ulbrich, G. Storm and F. Kiessling, ACS Nano, 2012, 7, 252-262. 
20 M. Pechar, R. Pola, R. Laga, K. Ulbrich, L. Bednárová, P. Maloň, I. Sieglová, V. Král, M. Fábry and O. Vaněk, Biomacromolecules, 2011, 12, 3645-3655.

21 V. Šubr, 亡̌. Koňák, R. Laga and K. Ulbrich, Biomacromolecules, 2006, 7, 122-130.

22 Č. Koňák, V. Šubr, L. Kostka, P. Štěpánek, K. Ulbrich and H. Schlaad, Langmuir, 2008, 24, 7092-7098.

23 D. Klepac, H. Kostkova, S. Petrova, P. Chytil, T. Etrych, S. Kereïche, I. Raska, D. A. Weitz and S. K. Filippov, Nanoscale, 2018, 10, 6194-6204.

24 N. Green, C. W. Herbert, S. Hale, A. Hale, V. Mautner, R. Harkins, T. Hermiston, K. Ulbrich, K. Fisher and L. Seymour, Gene Ther., 2004, 11, 1256.

25 V. Král, P. Mader, R. Collard, M. Fábry, M. Hořejší, P. Řezáčová, M. Kožíšek, J. Závada, J. Sedláček and L. Rulíšek, Proteins: Struct., Funct., Bioinf., 2008, 71, 12751287.

26 S. Pastorekova, S. Parkkila, A. K. Parkkila, R. Opavsky, V. Zelnik, J. Saarnio and J. Pastorek, Gastroenterology, 1997, 112, 398-408.

27 P. C. McDonald, J.-Y. Winum, C. T. Supuran and S. Dedhar, Oncotarget, 2012, 3, 84.

28 J. Zavada, Z. Zavadova, J. Pastorek, Z. Biesova, J. Jezek and J. Velek, Br. J. Cancer, 2000, 82, 1808.

29 A. Chrastina, J. Zavada, S. Parkkila, Š. Kaluz, M. Kaluzová, J. Rajčáni, J. Pastorek and S. Pastoreková, Int. J. Cancer, 2003, 105, 873-881.

30 V. Tokárová, A. Pittermannová, V. Král, P. Řezáčová and F. Štěpánek, Nanoscale, 2013, 5, 11490-11498.

31 M. Ullrich, J. Haša, J. Hanuš, M. Šoóš and F. Štěpánek, Powder Technol., 2016, 295, 115-121.

32 A. Watermann and J. Brieger, Nanomaterials, 2017, 7, 189.

33 Y. Zhang, J. Guo, X.-L. Zhang, D.-P. Li, T.-T. Zhang, F.-F. Gao, N.-F. Liu and X.-G. Sheng, Int. J. Pharm., 2015, 496, 10261033.
34 M. Bouchoucha, É. Béliveau, F. Kleitz, F. Calon and M.-A. Fortin, J. Mater. Chem. B, 2017, 5, 7721-7735.

35 T. Mandal, M. Beck, M. Lindén and C. Buske, Blood, 2016, 128, 4713.

36 F. Chen, H. Hong, Y. Zhang, H. F. Valdovinos, S. Shi, G. S. Kwon, C. P. Theuer, T. E. Barnhart and W. Cai, ACS Nano, 2013, 7, 9027-9039.

37 J.-K. Wang, Y.-Y. Zhou, S.-J. Guo, Y.-Y. Wang, C.-J. Nie, H.-l. Wang, J.-l. Wang, Y. Zhao, X.-Y. Li and X.-J. Chen, Mater. Sci. Eng., C, 2017, 76, 944-950.

38 Clinical Trial ID no. NCT02106598, Targeted Silica Nanoparticles for Real-Time Image-Guided Intraoperative Mapping of Nodal Metastases.

39 D. E. Owens III and N. A. Peppas, Int. J. Pharm., 2006, 307, 93-102.

40 M. Cataldi, C. Vigliotti, T. Mosca, M. Cammarota and D. Capone, Int. J. Mol. Sci., 2017, 18, 1249.

41 E. Blanco, H. Shen and M. Ferrari, Nat. Biotechnol., 2015, 33, 941.

42 T. Etrych, T. Mrkvan, P. Chytil, Č. Koňák, B. Ríhová and K. Ulbrich, J. Appl. Polym. Sci., 2008, 109, 3050-3061.

43 S. Pastoreková, Z. Závadová, M. Koštál, O. Babušíková and J. Závada, Virology, 1992, 187, 620-626.

44 W. Stöber, A. Fink and E. Bohn, J. Colloid Interface Sci., 1968, 26, 62-69.

45 J. Čejková, J. Hanuš and F. Štěpánek, J. Colloid Interface Sci., 2010, 346, 352-360.

46 Bangs Laboratories, Inc., TechNote 205: Covalent Coupling, 2013.

47 N. Touisni, N. Kanfar, S. Ulrich, P. Dumy, C. T. Supuran, A. Mehdi and J.-Y. Winum, Chem.-Eur. J., 2015, 21, 1030610309. 